hymnem Litwy. „Tekst rozdzielający dwie tożsamości” (Daujotytė, Kvietkauskas 130) Miłosz starał się w okolicach roku 1990, a więc w momencie odradzania się wolnej państwowości Polski i Litwy, przetłumaczyć jako czytelny znak pragnienia jednoczesnego odnawiania wspólnoty i niezamazywania różnic - ,jako łączący, niezbędny dla nadchodzącego czasu współegzystowania" (Daujotytė, Kvietkauskas 130). Jego przekład - przekonują autorzy książki - jest swoistym przepisywaniem tekstu, mediacją, która ma umożliwić zmniejszenie dystansu pomiędzy dwoma tożsamościami (polską i litewską) przy jednoczesnym zachowaniu odrębności wartości niezgodnych ze sobą.

Pragnienie to w oczywisty sposób pozostaje także wyborem autorów pracy o Litewskich kontekstach Czestawa Miłosza. Książki tak dla polonisty, jak i dla lituanisty - niezwykle ważnej i cennej. Jej wartość tkwi nie tylko w bogactwie informacji (choć tego poznawczego wymiaru nie sposób przecenić). Wagę pracy w jeszcze większej mierze określa przesłanie o możliwości i konieczności kulturowego dialogu, do którego nakłaniać nas winny nasze, w jakimś stopniu zawsze pograniczne, biografie.

\title{
BIBLIOGRAFIA
}

Daujotytė Viktorija, Kvietkauskas Mindaugas. Litewskie konteksty Czesława Miłosza. Sejny: Wydawnictwo Pogranicze, 2014.

Miłosz, Czesław. Szukanie ojczyzny. Kraków: Znak, 1992.

Miłosz, Czesław. Autoportret przekorny. Rozmowy przeprowadzit Aleksander Fiut. Kraków:Wydawnictwo Literackie, 1994a.

Miłosz, Czesław. Ziemia Ulro. Kraków: Wydawnictwo Literackie, 1994b.

\section{NARODNICTWO JAKO KONIECZNOŚĆ}

\author{
RYSZARD KUPIDURA ${ }^{3}$ \\ (Uniwersytet im. Adama Mickiewicza w Poznaniu)
}

Portnova, Tetjana. Ljubyty i navčaty: seljanstvo v ujavlennjach ukrajins'koji intelihenciji druhoji polovyny XIX stolittja. Dnipropetrovs'k: Lira, 2016. 240 S.

Nawiązując do spopularyzowanego głównie przez rosyjskiego badacza Alexandra Etkinda oksymoronicznego terminu „wewnętrzna kolonizacja” (Bakuła 342-344) można pokusić się o odczytanie pracy dnieprzańskiej historyczki Tetiany Portnowej

3 E-mail: ryszardk@amu.edu.pl 
poświęconej reprezentacji chłopów w dyskursie ukraińskiej inteligencji II połowy XIX wieku jako historii projektu emancypacyjnego ukraińskich elit. Ów projekt miałby polegać na symbolicznym wykorzystaniu rodzimego subalterna $\mathrm{w}$ celu stworzenia podstaw do zrzucenia własnej zewnętrznej zależności w strukturze władzy wyższego rzędu i wybicia się na niepodległość.

$\mathrm{W}$ istocie zainspirowana romantycznymi ideami ukraińska inteligencja, rozpoczynając proces budowy nowoczesnego narodu, musiała oscylować pomiędzy projektem ekskluzywnym (naród kozacki) oraz inkluzywnym (lud ukraiński). Pamięć o kozackiej tradycji była ważna dla zachowania ciągłości i tradycji, jednak to idea chłopstwa jako fundamentu narodu zaczęła odgrywać wiodącą rolę w ukraińskiej literaturze oraz myśli społeczno-politycznej, co w danym okresie historycznym oznaczało często to samo i funkcjonowało wspólnie pod szyldem narodnictwa.

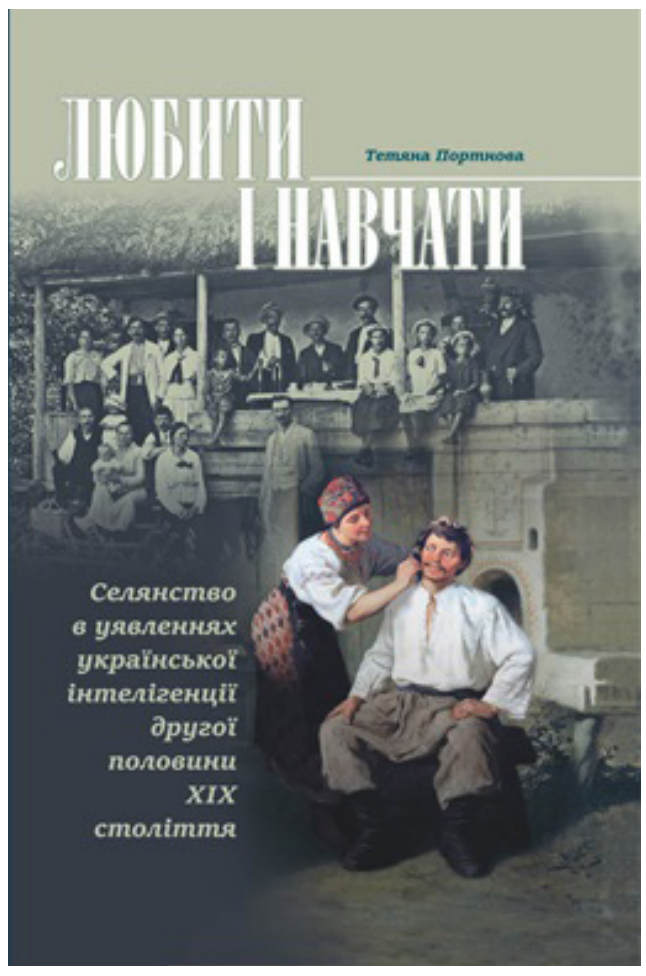

$\mathrm{W}$ pewnym sensie ruch narodnicki w historii ukraińskiej kultury padł ofiarą własnych praktyk dyskursywnych. Generując i esencjalizując przez lata rozliczne heteroobrazy, ostatecznie sam został opisany i skatalogowany przez swych krytyków (najpopularniejsze definicje ruchu narodnickiego można znaleźć w napisanych pod koniec XX wieku pracach Sołomiji Pawłyczko, Oksany Zabużko czy George'a G. Grabowicza), którzy rozwój ukraińskiej kultury widzieli głównie jako proces przezwyciężania antymodernistycznych syndromów narodnictwa.

Wśród zadań, które w swojej pracy realizowała Portnova, znalazła się zatem próba rehabilitacji myśli narodnickiej, która według autorki nie była jedynie egzaltowaną projekcją idealnego chłopa, ale także etapem koniecznym w budowie nowoczesnego społeczeństwa. Kult ludu był zdaniem historyczki jedynym możliwym do zrealizowania wariantem projektu narodowego. Ukraiński przypadek nie stanowił tym samym wyjątku w historii społeczeństw Europy Środkowej i Wschodniej, w których chłopstwo, jak zauważył polski historyk Włodzimierz Mędrzecki, było jednocześnie fundamentem i balastem dla procesów modernizacyjnych (Portnova 13).

Ljubyty $i$ navčaty nie jest kolejną pozycją z historii ukraińskiego chłopstwa, nie aspiruje też do wpisania się $\mathrm{w}$ zapoczątkowany jeszcze $\mathrm{w}$ latach sześćdziesiątych XX wieku i wciąż bardzo aktualny nurt odzyskiwania głosu wykluczonych społecznie i politycznie grup. Jeśli głos chłopa ma być w niej słyszalny, to jedynie jako echo 
wypowiedzi inteligenta, który wielokrotnie wyrażał swoje rozczarowanie, a niekiedy irytację, w sytuacjach, kiedy obiekt deskrypcji nie wpisywał się w aprioryczne ramy idealnego obrazu. Portnova przesunęła w swej pracy akcent $\mathrm{z}$ poszukiwania odpowiedzi na pytanie o zbieżność spostrzeżeń dziewiętnastowiecznych myślicieli $\mathrm{z}$ autentycznym obrazem wsi na badanie przyczyn takiego, a nie innego przedstawiania chłopów w danym momencie historycznym. „To, co chłopstwo symbolizowało, było ważniejsze niż to, czym ono było naprawdę" (tu i dalej - tłum. R.K.) - zauważa autorka w podsumowaniu książki (Portnova 193). Wśród interesujących egzemplifikacji znalazł się m.in. fakt, że na Naddnieprzańskiej Ukrainie zbieracze folkloru nie podkreślali szczególnej religijności chłopów. Portnova tłumaczy to tym, że w przeciwieństwie do Galicji, gdzie kościół greckokatolicki był ważnym aspektem budowania tożsamości narodowej podczas kontaktów z katolikami, na lewym brzegu Dniepru przynależność wyznaniowa nie pokrywała się z podziałami etnicznymi i jako taka nie znajdowała się w centrum uwagi budzicieli narodu (Portnova 135). Na tym obszarze w celu generowania różnic popularyzowano tezę o indywidualistycznym i prodemokratycznym usposobieniu ukraińskiego chłopa. W danym przypadku w charakterze kontrapunktu występowała tradycyjna rosyjska wspólnota wiejska - obszczina (Portnova 130).

Spotkanie ukraińskiej inteligencji z chłopstwem Portnova opisuje jako rodzaj specyficznego targu. Przypomina to tezę Tamary Hundorowej o jarmarku jako miejscu oraz mechanizmie, za pomocą którego tworzył się nowoczesny naród ukraiński wraz ze swoją kulturą (Hundorova 332). Etnograficzne ekspedycje pobierały formy i treści z ludowego żywiołu, które po modyfikacjach powracały do niego już w formie kultury narodowej. Wyszywana koszula przestała być w ten sposób jedynie elementem tradycyjnego ubioru ludowego, zamieniając się $\mathrm{w}$ artefakt kulturowy oraz manifest poglądów politycznych jej właściciela. Wektory opisanego wyżej mechanizmu bywały niekiedy zwrócone w przeciwnym kierunku i to wieś według własnych upodobań udamawiała idee i obrazy, które z zewnątrz przynosiła jej inteligencja. Dla przykładu praktyka niesienia pod strzechy twórczości Tarasa Szewczenki wraz ze stylizowanym portretami poety stała się od lat sześćdziesiątych XIX wieku ważnym czynnikiem szerzenia idei narodowej wśród chłopów. Ponad dziesięciotysięczne nakłady „Kobziarza” na początku XX wieku świadczą o tym, że Szewczenko rzeczywiście stał się ikoną ukraińskiej wsi, jednak już w przetransponowanym obrazie chłopskiego watażki, któremu bliżej było do Stieńki Razina i Jemieljana Pugaczowa aniżeli do Iwana Kotlarewskiego z jego nieprzystępną i niezrozumiałą dla chłopów Eneida (Portnova 90-91). Tradycyjne przedstawianie Szewczenki w czapce i kożuchu, któremu to wizerunkowi sprzeciwiają się kolejne pokolenia ukraińskich intelektualistów (ostatnio wydawca i poeta Iwan Małkowycz w głośnym wystąpieniu podczas wręczania Nagrody Narodowej imienia T. Szewczenki), jest głęboko zakorzenione w kolektywnej świadomości Ukraińców i, jak dowodzi książka Portnowej, nie daje się wytłumaczyć jedynie socrealistyczną inter- 
pretacją z czasów radzieckich. Do innych, aktualnych do dzisiaj problemów ukraińskiej rzeczywistości społecznej, których genezy można doszukiwać się w praktykach ruchu narodnickiego, należała m.in. niejednoznaczna postawa wobec kwestii językowej. Inteligencja z jednej strony pragnęła ukraińskojęzycznego ludu, który miał stworzyć podwaliny pod przyszły naród, jednak w konkretnym czasie historycznym uważała za zbyt ryzykowne, by posyłać do ukraińskich szkół również własne dzieci, które wykształcenie zdobywały zazwyczaj w rosyjskich gimnazjach (Portnova 97). Tym samym chłopi zetknęli się ze zjawiskiem, które dzisiaj nazwano by zapewne "szklanym sufitem”, przy czym czynnikiem wykluczającym była w tym wypadku nie płeć czy rasa, a język. Hipokryzja narodników była oczywista dla samych chłopów, którzy organizowali nawet protesty przeciwko wprowadzaniu języka ukraińskiego do szkół. Dopiero w 1893 roku radykalnie nastawiona młodzież z Bractwa Tarasowców (był wśród niej m.in. pisarz Mychajło Kociubynski), reprezentująca nowe pokolenie $w$ ruchu narodowym, postulowała używanie języka ukraińskiego w każdej sferze życia codziennego i obstawanie przy nim nawet w zrusyfikowanym środowisku.

Wraz z rozwojem ukraińskiej myśli społecznej zmieniał się wzorzec idealnego chłopa, który de facto tożsamy był z ideałem obywatela. Niektóre z cech chłopskich zmieniały status z pożądanych na niechciane. Gloryfikowane przez romantyków zacofanie wsi, mające oznaczać bliskość ich mieszkańców i natury oraz przestrzeganie przez nich jakiegoś szczególnego kodeksu moralnego, w ostatnich dekadach XIX wieku było oceniane negatywnie jako przyczyna wszelkich nieszczęść na wsi. Narodnicy z trudem uświadamiali sobie fakt, że szlachetne uczucia altruizmu i miłosierdzia nie przeszczepiają się łatwo na grunt surowego wiejskiego życia, gdzie godność człowieka bezpośrednio związana była z przydatnością do pracy w gospodarstwie. „Najstraszniejszym przeczuciem ukraińskiego narodnictwa, nie wypowiedzianym nigdy na głos, stało się uzmysłowienie, że lud jest tak samo niedoskonały, a być może i gorszy niż jego wykształceni sympatycy" (Portnova 159) - pisze w swej książce Portnowa.

Owo przeczucie towarzyszyło ukraińskim zwolennikom ludowości już od lat sześćdziesiątych XIX wieku, kiedy to w Imperium Rosyjskim została zniesiona pańszczyzna. Reforma rozpoczęła procesy stratyfikacji społecznej na ukraińskiej wsi i spowodowała pojawienie się nowej grupy społecznej, którą stanowili zamożni chłopi. Od tej pory ciemiężyciel i wyzyskiwacz nie mógł być kojarzony jednoznacznie z etnicznym Innym. W literaturze tego okresu zaczęła pojawiać się postać rodzimego eksploatatora, który bywa bardziej bezwzględny aniżeli dawny pan. Zdanie z jednego dramatów Marka Kropywnyckiego „Dziś gorzej niż za pańszczyzny!” (cyt. za: Portnova 171) oddaje istotę ludowej historiozofii i może stanowić jeszcze jeden wariant mitu „złotego wieku”, w którym brakuje odwołania do czasów obfitości i szczęścia, natomiast pielęgnowana jest pamięć o czasie rzekomego mniejszego wyzysku. 
Książka Ljubyty $i$ navčaty... Portnowej jest pozycją porządkującą stan wiedzy na temat ważnego nurtu w historii ukraińskiej kultury. Autorka oparła się mało już dzisiaj produktywnej pokusie dekonstrukcji kolejnych mitów generowanych na przestrzeni dziesięcioleci przez myśl narodnicką. Mity te pokazuje raczej jako do pewnego stopnia konieczne i naturalne strategie rozwoju, charakterystyczne dla większości ruchów narodowych Europy Środkowej i Wschodniej. Konserwatyzm, odrzucenie kapitalizmu oraz antyurbanizm były filarami, które miały nie tyle uchronić przed utratą tożsamości narodowej, co stworzyć odpowiednie środowisko dla jej krystalizacji. Praca Portnowej nie tylko tłumaczy źródła obecnych do dzisiaj aksjomatów kultury ukraińskiej, ale wyjaśnia wraz z tym wiele zjawisk i problemów współczesnego życia społecznego i politycznego na Ukrainie. Badaczka nie ucieka się wprawdzie do publicystyki i nie przeprowadza prostej paraleli pomiędzy dziewiętnastowieczną rzeczywistością a bieżącą polityką, jednak podczas lektury Ljubyty i navčaty... jako żywo stają przed oczami dzisiejsze dylematy naszych wschodnich sąsiadów.

\title{
BIBLIOGRAFIA
}

Bakuła, Bogusław. "Rosyjska wewnętrzna kolonizacja”. Porównania 15 (2014). S. 341-356.

Hundorova, Tamara. Tranzytna kultura. Symptomy postkolonialnoji travmy. Kyjiv: Grani-T, 2013.

\section{NOŻYCZKI NORWIDA}

\author{
ELIZA KĄCKA ${ }^{4}$ \\ (Uniwersytet Warszawski)
}

Borowiec, AnNA. "Album Orbis" Cypriana Norwida jako księga sztukmistrza. Gdańsk: Słowo/obraz terytoria, 2016. $418 \mathrm{~S}$.

W opowiadaniu Fama Jarosław Iwaszkiewicz pisał:

Prof. Stanisław Wolski, zasłużony historyk sztuki, lat 76 [...], znajdował się w sali gotyckiej, pochylony nad ołtarzem z Nawiedzeniem; pisał on pracę o wpływie polskiej rzeźby dolnopomorskiej i szczecińskiej na sztukę Leonarda da Vinci, i właśnie ten ołtarz, co prawda pochodzący z Gór Świętokrzyskich, ale zawierający w sobie wpływy mistrza Jana, nadwornego rzeźbiarza księcia Kaźka szczecińskiego, wnuka Kazimie-

4 E-mail: eliza.kacka@gmail.com 